\title{
The utilization of Jackfruit seed flour (Artocarpus heteropyllus) as substitution of rice bran in rations on Kampung chicken performances
}

\author{
Jekson Pasaribu, E Mirwandhono, S, Hamdan and N D Hanafi \\ Animal Production Program, Faculty of Agriculture, Universitas Sumatera Utara, \\ Medan 20155 \\ E-mail: nurzainahginting@gmail.com
}

\begin{abstract}
The objective of this research is analyze the extent to which the utilization of jackfruit seed flour can substitute rice bran in rations on the performance of chicken. This research was conducted in laboratory of livestock breeding livestock study program of agricultural faculty of north sumatera university, in March-April 2017. The design used in this research is randomized block design (RAK) with 4 treatments and 3 groups. Treatment with various levels of jackfruit seed meal ration with P0 (0\%), P1 (10\%), P2 (20\%), P3 (30\%). The parameters in this study are ration consumption, weight gain and ration conversion.The results showed the average consumption (g/ head / day) for treatment P0; P1; P2; P3 of; 349,53; 345,$71 ; 354.28 ; 343.67$, then weight gain (PBB) (g / head / day) were; 98,85; 100,41; 92.49; 100.8 , and ration conversion of; $6.36 ; 6.28 ; 6.87$ and 6.21 . The results of the diversity analysis showed that the utilization of Jackfruit seed flour gave no significant effect $(\mathrm{P}>0,05)$ on the performance of chicken. The conclusion of this research is the use of jackfruit seed flour in ration can substitute rice bran in chicken ration.
\end{abstract}

\section{Introduction}

Rice bran is a feed material that has been widely used by some farmers in Indonesia. Some of the feed ingredients derived from agro-industrial waste. Bran has great potential as a feed source of energy for livestock [1]. The main disadvantage is the content of crude fiber is quite high, ie $13.0 \%$ and the presence of phytate compounds that can bind minerals and proteins that can be difficult to be utilized by digestive enzymes. This is the limiting factor of its use in the preparation of the ration.

Jackfruit seed is a material that is often wasted after consumed although there is a small part of the community who process it to be food for example processed into kolak. Jackfruit seeds are round to oval, small size of less than $3.5 \mathrm{~cm}$, two pieces and the average of each fruit jackfruit contains seeds that weigh one third of the weight of the fruit. The number of seeds per 150-350 seeds and the length of the jackfruit seeds is about $3.5 \mathrm{~cm}-4.5 \mathrm{~cm}$. In terms of nutritional content, jackfruit seed flour has a nutritional content that is almost close to the nutrient content in rice bran. So it appears the researchers thought to do penetitian about the utilization of jackfruit seed flour as substitution of rice bran on the performance of chicken.

\section{Materials and Methods}

This research was conducted at Animal Husbandry Laboratory of Animal Husbandry Study Program Faculty of Agriculture University of Sumatera Utara Medan. 
DOC chicken as much as 100 feed concentrate consisting of jackfruit seeds, corn flour, rice bran, fish meal, soybean meal, coconut meal, palm kernel cake (BIS), oil and mineral flour. Drugs such as the ND vaccine and the gumboro vaccine, rhodalon to clean the feed and take vitamins. Drinking water provided ad libitum. The research method used was non factorial randomized block design (RAK) with 4 treatments and 3 groups.

\subsection{Parameter of Research}

\subsubsection{Ration consumption}

Ration consumption $=$ Initial ration $(\mathrm{g})$ - residual ration $(\mathrm{g})$

\subsubsection{Increase of Body Weight}

Increase of Body Weight $=$ End body weight $(\mathrm{g})$ - initial body weight $(\mathrm{g})$

\subsubsection{Feed Conversion Ratio}

$$
\text { Feed Conversion Ratio }=\frac{\text { Feed Consumption }(\mathrm{g})}{\text { Increase of Body Weight(g) }}
$$

\subsection{Implementation of Research}

1. Preparation of the cage and equipment

2. Preparation of jackfruit seeds

4. Preparing for domestic poultry

5. Preparation of Rations

6. Feeding

7. Data retrieval

8. Test Data Analysis

\section{Results and discussion}

\subsection{Consumption of Rations}

Ration consumption is the number of rations eaten by livestock will be used to provide basic living and for livestock production. The consumption of the ration can be calculated by reducing the amount of ration given with the residual feed on the feed.

Table 1. Average consumption of chicken ration during the study

\begin{tabular}{llllllc}
\hline Treatment & KI & KII & KIII & Total & Average & sd \\
\hline P0 & 342,71 & 345 & 360,89 & 1048,60 & 349,53 & $\pm 9,90$ \\
P1 & 343,21 & 345,17 & 348,75 & 1037,13 & 345,71 & $\pm 2,80$ \\
P2 & 355 & 345 & 362,85 & 1062,85 & 354,28 & $\pm 8,94$ \\
P3 & 333 & 345,71 & 352,32 & 1031,03 & 343,67 & $\pm 9,80$ \\
\hline Total & 1373,92 & 1380,88 & 1424,81 & 4179,61 & & \\
\hline Average & 343,48 & 345,22 & 356,2025 & & 348,40 & \\
\hline
\end{tabular}

Jackfruit seed flour in the rations showed no significant effect on consumption. This is consistent with the statement of Kartadisastra (1994) which states that the high consumption of feed is influenced by external factors, namely the environment and the internal factor or condition of the livestock covering the environmental temperature, palatability, physiology status ie age, sex and body condition, nutrient concentration, form of feed, body weight, and production [2]. 
Table 2. Analysis of the variety of chicken ration consumption during the study

\begin{tabular}{lllllll}
\hline \multirow{2}{*}{ SK } & \multirow{2}{*}{ DB } & \multirow{2}{*}{ JK } & \multirow{2}{*}{ KT } & \multirow{2}{*}{ F Count } & F Table & \\
\cline { 6 - 7 } & & & & & 0,05 & 0,01 \\
\hline Group & 2 & 380,67 & 190,33 & 6,20 & 19,33 & 99,33 \\
Treatment & 3 & 196,21 & 65,40 & $2,13^{\text {tn }}$ & 8,94 & 27,91 \\
Galat & 6 & 184.10 & 30,68 & & & \\
Total & 11 & 760,99 & 286,41 & & & \\
\hline Description: tn & & & &
\end{tabular}

Description: $\mathrm{tn}=$ not real

Feed consumption of livestock is affected by the condition of the livestock itself and the condition of the environment at the time of maintenance thus affecting the consumption level of chicken. This is in accordance with the statement of Sanusi (2006) which states that the consumption of animal feed should be known to be able to optimize the amount of feed given, because the feeding is less than optimal will result in the growth of livestock less than maximum [3].

\subsection{Increase of Body Weight}

The weight gain (PBB) includes growth in the form of heavy build-up tissues such as: bone, heart, brain, and all other body tissues (except fat tissue) and body tools. Weight gain can be measured by subtracting the final body weight by the initial weight of time unity in grams / head / week. Weighing is done once a week.

Table 3. The average rate of chicken body weight ( $\mathrm{g} /$ ekor / minggu)

\begin{tabular}{llllllc}
\hline Treatment & KI & KII & KIII & Total & Average & Sd \\
\hline P0 & 75,62 & 107,18 & 113,75 & 296,555 & 98,85 & $\pm 20,38$ \\
P1 & 74,06 & 107,81 & 119,37 & 301,245 & 100,41 & $\pm 23,54$ \\
P2 & 74,37 & 108,43 & 94,68 & 277,485 & 92,49 & $\pm 17,13$ \\
P3 & 73,12 & 108,75 & 120,62 & 302,5 & 100,83 & $\pm 24,71$ \\
\hline Total & 297,18 & 432,17 & 448,43 & 1177,78 & & \\
\hline Average & 74,29 & 108,04 & 112,10 & & 98,14 & \\
\hline
\end{tabular}

The result of analysis of diversity of body weight gain showed different result was not significant to the increase of chicken body weight. This is due to the consumption of relatively similar feed and nutritional content of the same feed. This is in accordance with the statement Soeparno (1992) which states that the consumption of dry matter and nutrient content of feed have a great influence on the increase of body weight of the livestock [4].

Table 4. Analysis of the variety of chicken body weight gain during the study

\begin{tabular}{|c|c|c|c|c|c|c|}
\hline \multirow{2}{*}{ SK } & \multirow{2}{*}{ DB } & \multirow{2}{*}{$\mathrm{JK}$} & \multirow{2}{*}{ KT } & \multirow{2}{*}{ F Count } & \multicolumn{2}{|c|}{ F Table } \\
\hline & & & & & 0,05 & 0,01 \\
\hline Group & 2 & 3445,74 & 1722,87 & 34,30 & 19,33 & 99,33 \\
\hline Treatment & 3 & 134,15 & 44,71 & $0,89^{\text {tn }}$ & 8,94 & 27,91 \\
\hline galat & 6 & 301.39 & 50,23 & & & \\
\hline total & 11 & 3881,28 & 1817,81 & & & \\
\hline
\end{tabular}

Description: $\mathrm{tn}=$ not real

Based on Table 4 it can be seen that the highest body weight gain is found in P3 of 100.83 gram / head / day while the lowest weight gain is found at P2 of 92.49. Based on the analysis of variance shows different results are not real (F Count $<0.05$ ) on consumption. This shows that the substitution of rice bran with jackfruit seed flour gives a very real effect on the increase of chicken body weight. This is 
consistent with the statement of Tillman et al. (1984) which states that livestock productivity is strongly influenced by the amount of feed and nutrients that can be utilized by livestock.

\subsection{Convert Rations}

Conversion of ration is the ratio between the amount of ration consumed by the increase of body weight in a certain period. Rasyaf (2004), states that, Conversion Ratio (Feed Converse Ratio) is the ratio of the amount of feed consumption in a week with the added body weight achieved in that week [5].

Table 5. Average conversion of chicken ration during the study.

\begin{tabular}{lllllll}
\hline Treatment & KI & KII & KIII & Total & Average & \pm sd \\
\hline P0 & 7,91 & 5,63 & 5,55 & 19,09 & 6,36 & $\pm 1,34$ \\
P1 & 8,13 & 5,6 & 5,11 & 18,84 & 6,28 & $\pm 1,62$ \\
P2 & 8,35 & 5,56 & 6,7 & 20,61 & 6,87 & $\pm 1,40$ \\
P3 & 7,98 & 5,56 & 5,11 & 18,65 & 6,21 & $\pm 1,54$ \\
\hline Total & 32,37 & 22,35 & 22,47 & 77,19 & & \\
\hline Average & 8,09 & 5,58 & 5,61 & & 6,43 & \\
\hline
\end{tabular}

The results of the analysis of conversion diversity of rations can be seen in Table 5 which shows that rice bran substitution with jackfruit seed flour showed different results not significantly on the conversion of rations. The results are not significantly different because of the use of jackfruit seed flour as rice bran substitution in the ration does not affect the weight gain and consumption of rations. This is in line with the opinions of Champbell and Lasley (1985) which suggest that factors affecting ration conversion are genetic, age, body weight, feed intake rate, body weight gain, palatability, and hormones [6].

Table 6. Analysis of variation of chicken ration conversion during the study

\begin{tabular}{|c|c|c|c|c|c|c|}
\hline \multirow{2}{*}{ SK } & \multirow{2}{*}{ DB } & \multirow{2}{*}{ JK } & \multirow{2}{*}{ KT } & \multirow{2}{*}{ F Count } & \multicolumn{2}{|c|}{ F Table } \\
\hline & & & & & 0,05 & 0,01 \\
\hline Group & 2 & 16,53 & 8,26 & 49,09 & 19,33 & 99,33 \\
\hline Treatment & 3 & 0,79 & 0,26 & $1,58^{\mathrm{tn}}$ & 8,94 & 27,91 \\
\hline Galat & 6 & 1,01 & 0,16 & & & \\
\hline total & 11 & 18,34 & & & & \\
\hline
\end{tabular}

Keteranagan : $\mathrm{tn}=$ berbeda tidak nyata

The highest ration conversion was in $\mathrm{P} 2$ of 6.87 while the lowest ration conversion was in P3 of 6.21 . Based on the analysis of variance, the results show that the different results are not significant $(\mathrm{F}$ Count $<0.05$ ) to the ration conversion. This is in accordance with Anggorodi's (1990) statement, which states that the ration conversion is the ratio between the amount of feed consumed by the added weight gain achieved in the same period [7].

\subsection{Recapitulation of Research Results}

To see the recapitulation of the results of the research on the utilization of jackfruit flour as a substitution of rice bran in the ration on the performance of chicken (consumption of rations, weight gain and feed conversion) can be seen in Table 7 below:

Table 7. Recapitulation of research results

Treatment $\quad$ Average parameter




\begin{tabular}{|c|c|c|c|}
\hline & $\begin{array}{l}\text { Konsumsi Pakan } \\
\text { (g/ekor/hari) }\end{array}$ & PBB (g/ekor/hari) & Konversi Pakan \\
\hline $\mathrm{P} 0$ & 349,53 & 98,85 & 3,53 \\
\hline P1 & 345,71 & 100,41 & 3,44 \\
\hline P2 & 354,28 & 92,49 & 3,83 \\
\hline P3 & 343,67 & 100,83 & 3,40 \\
\hline
\end{tabular}

\section{Conclusions}

Utilization of jackfruit seed flour can replace rice bran in rations on the performance of chicken chickens in terms of consumption of rations, weight gain and ration conversion.

\section{References :}

[1] Scott, M. L, M. C. Neisheim dan R. J. Young. 1982. Nutrition of Chiken. 3rd Edition, Published M, L Scott and Associates: Ithaca, New York.

[2] Kartadisastra, H.R 1994 Komposisi Kandungan Bahan Penyusun Ransum. Kanisius, Yogyakarta

[3] Sanusi,A.2006.PengaruhPenambahan Starbio Dalam Ransum Terhadap Kecernaan Bahan Kering dan Bahan Organik Pada Ternak. Skripsi s1 Fakultas Pertanian Universitas Sebelas maret, surakarta

[4] Soeparno, 1992. Ilmu dan teknologi daging fakultas peternakan universitas gadjah mada, Yogyakarta

[5] Rasyaf, M. 2004. Beternak Ayam Pedaging. Penebar Swadaya. Jakarta.

[6] Champbell, J.R and J.F Lasley. 1985 the science of Animals that sarved mankin $3^{\text {th }}$. Tata M Graw. Hill publishing company limited new delhi.

[7] Anggorodi, R. 1990. Ilmu Makanan Ternak Umum. Gramedia, Jakarta. 